\title{
Jak v praxi ovlivnit spory o hranice? Proč se nepodařilo prírodovědce přesvědčit o významnosti genderu'
}

\author{
How to Tell Boundary Corrosive Stories? Revisiting Failures to \\ Render Gender a Matter of Concern with Natural Scientists
}

Dagmar Lorenz-Meyer

\begin{abstract}
As one genre of establishing difference and similarity the exploration of boundary drawings has been at the heart of feminist theory and practice. This article suggests that the sophistication of feminist boundary analyses may have not been matched with the ability of gender studies practitioners to effect boundary contestations in practice. Inspired by considerations in feminist science studies that we tell more complex stories and take responsibility for the boundaries we construct, I revisit narrative practices in a seminar presentation where former research participants had rejected my interpretations of gender in science. Taking the example of boundary drawings in presenting equality policies, gender statistics and personal narratives as well as discussions about accountability for sexist joking and research assessment, I argue that mono-causal and naturalised understandings of gender relations are best challenged by presenting more varied gender practices, taking risks in pointing to ambivalences in particular kinds of data and gender as a knowledge object, and by starting from the concerns articulated by powerful, not marginalised actors. The conclusion discusses what research practices and infrastructures may be conducive for telling boundary corrosive stories.
\end{abstract}

KEY WORDS boundary drawing practices, gender in science, interference, accountability, research presentation

\section{Úvod}

Feministické bádání jako analytická tradice a intervencionistický projekt „zabývající se vytvářením odlišnosti nejen mezi mužským a ženským, ale také mezi druhy a typy“ (Franklin a kol. 2000: 6) již dlouho zkoumá hranice, jež jsou tak hluboce vepsány do západního myšlení a pojetí racionality. Vytyčování hranic souvisí s jejich teritoriálními aspekty (jak patrno též ze slovanského původu slova hranice: grab-nica od slova hrabat nebo kopat - př́kopy mezi zeměmi) a je jedním ze způsobů, jak stanovovat rozdílnost a podobnost. Vytyčená hranice „sloučí dohromady to, co se podobá, a představí si nebo vytvoří okolo toho hranici. To, co je jiné, je potom také jinde“ (Mol 2002: 135). Feministická teorie se zabývá prostupností

Sociálni studia. Katedra sociologie FSS MU, 3/2012. S. 65-83. ISSN 1214-813X.

1 Chtěla bych poděkovat Cathrine Hasse a Elviře Scheich za užitečné komentáře k předešlé verzi rukopisu a Tereze Kodíčkové za precizní, promyšlený a pozorný překlad textu. 
a proměnlivostí hranic, stavbou hierarchických vztahů a skrytou propojeností toho, co je udržováno v oddělenosti, a toho, co nezapadá - a co tedy není ani tím, ani oním (např́klad Minh-ha 1986/7; Star 1991; Butler 2004).

Tento článek vychází z myšlenky, že schopnost v praxi destabilizovat hranice pokulhává za důmyslností analýz opakovaného utváření hranic. Jádrem feministické praxe je zájem zpochybňovat nákresy hranic a měnit to, co je považováno za přirozené, normální či skutečné. Mimo svůj vlastní „okrsek“ však feministé a feministky mohou být při tvoření těchto interferencí do přjímaných způsobů myšlení a jednání méně úspěšní. To jsem pochopila po diskusi na téma gender ve vědě, kdy praktikující vědkyně a vědci po ukončení fáze zúčastněného pozorování v rámci projektu Knowledge, Institutions and Gender (KNOWING) odmítli řadu př́iběhů a výkladů, se kterými jsem přrišla. ${ }^{2}$ Konkrétně jsem nebyla schopna z genderu učinit bohatě rozvrstvený ,předmět zájmu“ (matter of concern) (Latour 2004) heterogenně usporádávaný $\mathrm{v}$ rámci různých praxí ${ }^{3}$ a vztahů, který v zásadě může být sestaven jinak (LorenzMeyer 2009). ${ }^{4}$ Namísto toho byla genderová odlišnost ustavena jako pevná věc kulturních a biologických faktů a odpovědnost byla zredukována či odmítnuta.

Článek se hlásí k feministické výzvě přijmout „,neúspěch“ výzkumné intervence a prozkoumat to, jak ,se může stát zdrojem nebo příležitostí pro nové (ač ne nutně účinnější) strategie, modely, interpretace a způsoby bytí“ (Perrons a Posocco 2009: 132; England 1994). V létě 2010 jsem se svou spolubadatelkou Marcelou Linkovou (Sociologický ústav AV ČR) prezentovala některá zjištění českého projektu KNOWING. Na prŕíkladu této prezentace o př́ležitostech a nebezpečích vědecké excelence přezkoumám své vlastní intervence a intervence svých diskusních partnerů. Konkrétněji chci přemýšlet o tom, jak vyprávět př́běhy, které naleptávají hranice (corrosive stories), abych použila sugestivní pojem Hirschauer a Mol (1995: 380). Takovéto „korozivní př́běhy“ nejsou psány z jednoho úhlu pohledu chtějí dokládat situovanou proměnlivost pohlaví/genderu a jeho nevyhraněnost. Nesou určitou „smyslnou kvalitu“ - nepokoušejí se „měnit názor svých čtenářů kritickými prostředky, [ale] namísto toho se snaží čtenáře svést ke změně vnímání“. A co je nejobtížnější, korozivní př́běhy riskují a „nesnaží se kontrolovat to, čeho chtějí dosáhnout“, protože v nich

2 Projekt „Knowledge, Institutions and Gender: An East-West Comparative Study“ (KNOWING) podpořila Evropská komise ve svém 6. rámcovém programu (SAS-CT-2005-017617). Z genderového a geopolitického pohledu zkoumal kontexty a kultury praxí, které vytvářejí znalosti ve společenských a přírodních vědách v Rakousku, České republice, Finsku, Velké Británii a na Slovensku $(<$ http://knowing.soc.cas.cz $>$ ).

3 Ve smyslu postupů - pozn. překladatelky.

4 Latour (2004: 235) rozlišuje „předměty zájmu“ (matters of concern) a „fakta“ (matters of fact) - v obou př́ípadech ,se na shromáždění objektu musí podílet řada věci“. Ovšem u fakt jsou tyto praxe a mediace stabilizované, jsou považovány za samožrejmost a jsou zneviditelněné, zatímco u předmětů zájmu vystupuje do popředí jejich rozmanitost, mnohost a rozpornost. Fakta vznikají z předmětů zájmu, ale mohou se také zpětně vmísit do bohatě situovaných a rozmanitých předmětů zájmu. Puig de la Bellacasa (2011: 87) poznamenává, že „slovo ,concern“ mění afektivní náboj myšlení a prezentace věcí, protože implikuje potíže, starosti a zájem“. Tento afektivní náboj se ve francouzském (faits disputés) a německém (umstrittene Tatsachen) překladu pojmu „,matter of concern" ztrácí. 
jde o zvýšsení reflexivity oboru (tamtéž). Takovéto strategie se jeví jako obzvláště důležité, je-li řeč o genderových nerovnostech, protože feministická práce bývá často považována za monotónní a předvídatelnou - „používá reifikované koncepty $\mathrm{k}$ manipulaci unavené sociální teorie a není to k ničemu kromě viny a nudy“ (Star 1991: 33). K tendenci vyhlašovat genderovou univerzalitu či dualitu vědy Keller (1987) před téměř dvaceti pěti lety napsala, že pro badatelky a badatele je těžké naučit se „počítat více než do dvou“.

Následující analýza bude vedena úvahami o tom, jak lépe hovořit o genderu a genderování, jak ho pojmenovat, aniž bychom ho zredukovali na něco pevného a jednotného a zkoumané znovu vepsali do dominantních reprezentací. Empiricky čerpám z výtahu z diskuse na semináři o genderu a odpovědnosti a $z$ terénních poznámek o dalších rozhovorech, které proběhly po semináŕi. Jaké hranice jsem se rozhodla já a ostatní účastnice a účastníci při tomto setkání zpochybnit? Které hranice byly v tomto procesu překresleny? Jaké mohly být jiné možnosti? Úvahy nad tím, jak mohly být konkrétní části dat situovány jinak, jsou vedeny „ani ne tak tím, aby příběh ,správně‘ vyzněl, ale aby ,odlišně‘ plynul“ (Haraway 2004: 108; viz též Hemmings 2011: kap. 5) a snahou posílit odpovědnost.

Text začíná krátkým náčrtem některých vhledů do praxe vytyčování hranic vyplývajících z feministického bádání. $V$ druhé části prozkoumám nákresy hranic a jejich nerozpoznané účinky v mých vlastních narativních postupech při prezentaci praxí rovnosti, využití genderových statistik a porovnávání výpovědí aktérů. Třetí část se zabývá tím, jak naše intervence vedly účastníky semináře různým způsobem $\mathrm{k}$ tomu, aby hovořili o vlastním chápání mocenských vztahů a odpovědnosti za sexistické vtipkování a procesy hodnocení výzkumu. $\mathrm{Na}$ závěr načrtnu, které postupy, výzkumné kontexty a infrastruktury se jeví jako podpůrné pro vyprávění př́běhů s potenciálem ovlivňovat spory o hranice.

\section{Feministické vhledy do praxe vyłyčování hranic}

Feministické teorie mají dlouhou tradici ve zkoumání způsobů, jak se genderové hranice prolínají s řadou dalších protikladů (mysl/tělo, kultura/příroda, já/ostatní) a jak je zastírána jejich dynamická souvztažnost. Jedním z klíčových vhledů interakcionistické a poststrukturální feministické práce je, že takovéto hranice nejsou dány (,„přírodou“ nebo „společností“), ale jsou to praktické výstupy běžně realizované v každodenních prostředích. ${ }^{5}$ Tyto hmotně-diskurzivní nákresy hranic mají svůj prostorový a časový charakter: oproti prostupnějšímu prostoru domova jsou např́klad vědecká pracoviště ,,vyhrazeným, vysoce specializovaným časoprostorem, kam jiné činnosti a zájmy pronikají jen omezeně a je to vnímáno jako nemístné“ (Massey 1995: 494). Tato praxe spoluutvář́i a posiluje určitý druh maskulinity. Hranice tedy mohou být polopropustné.

Mohou se také uspořádat tak, že začlení to, co je na druhé straně vyloučeno, a „to druhé““ se pak stane nutnou součástí definice ,já“ (Mol a Law 2005). Nový typ vědecké maskulinity

To lze usoudit již z argumentace Wollstonecraft, že „především ženy čini slabými a méněcennými různé související př́íčiny“ (1992: 3, kurzíva autorka), hlavní mezi nimi je každodenní vyloučení žen ze vzdělání a politické účasti. To, co se jeví jako neměnná hranice charakteru pohlaví, se pak považuje za změnitelné prostřednictvím zvýšené společenské účasti. 
„experimentujícího muže“ v 17. století např́ílad zahrnoval ctnosti skromnosti, zdrženlivosti a svědomitosti, asociované s ženskostí. Ukazuje se tak nestabilita a proměnlivost genderových hranic, se kterými bylo třeba nakládat velmi opatrně tváŕí $\mathrm{v}$ tvár̆ přízraku zženštilého muže (nebo maskulinní ženy) (Potter 2001). Dále, hranice typu a druhu se často definují navzájem, takže ukazatele hranic maskulinity jako aktivita, racionalita a občanskost také spoluutvářejí (ideální) rasovou bělost. ${ }^{6}$ Ideální představa „evropského občanského mužstvi““ vznikla spojením „rasových, třídních, národnostních, sexuálních a genderovaných formací (nikoliv esencí)“ (Haraway 1997: 30) a zformovala to, co mohlo být považováno za vědecké poznatky. Ze zjištění, že i sexuální odlišnost je rasově nebo třídně specifická, vyplývá rozšíření genderových hranic, které oddělují maskulinitu dělnické tř́́dy od maskulinity střední třídy atd. Faulkner (2000) tvrdí, že ve vědecké praxi panuje napětí mezi modem abstraktního myšlení spojovaným s maskulinitou vyšších tříd a vtěleným modem maskulinity dělnické třídy s její ad hoc improvizací a kutilstvím, jež by mohlo být kódováno také jako femininní (Lorenz-Meyer 2011).

Tato složitost však neznamená, že kreslení hranic ztrácí svůj význam. Feminističtí teoretici a teoretičky od počátku tvrdili, že hmotně-diskurzivní nákresy hranic, včetně hranic ustavených feministkami a feministy, nejsou nikdy nevinné: jsou to akty osobování si moci, hodnoty a zdrojů, za něž musíme převzít odpovědnost (Haraway 1985; Fuss 1989). Snaha posunout nebo zpochybnit hranice pomáhá vynést na povrch otázky moci. Přesto však nemůžeme na hranice prostě zapomenout. Slovy Barad (1996: 187): „Hranice nejsou naši nepřátelé; jsou nutné k ustavování významů, ale to je nečiní nevinnými. Hranice mají reálné hmotné důsledky - řezy jsou umístěny agentně7 a odpovědnost je povinná“. Následující analýza je pokusem prijít na to, jak by to mohlo fungovat $\mathrm{v}$ praxi.

\section{Posunování hranic vědecké excelence, vymezování genderu}

V roce 2010 jsme společně s Marcelou Linkovou vedly seminář „Př́ležitosti a úskalí na cestě za vědeckou excelencí" na významné přírodovědecké instituci, kde proběhl i náš původní výzkum. Název semináře převzal ambici této instituce dosáhnout mezinárodního uznání. Při institucionální restrukturalizaci, která probíhala v době našeho výzkumu v letech 2006-2008, byla vědecká excelence v popředí zájmu. Organizačně se projevila zrušením stávajících oddělení a stálých smluv, proběhlo mezinárodní výběrové řízení na vedoucí výzkumných skupin, kteří pak mohli príijmout nové či stávající pracovníky dle vlastní volby, a bylo zavedeno každoroční hodnocení výzkumu, na němž závisí obnovení výzkumných skupin (Linková 2009).

6 A bělost - stejně jako maskulinita - nebyla nikdy prostě dána, byla konstruována: „Běloši se nerodí, běloši se tvoří “ (Jacobson 1999: 4), jak pečlivě doložili kritičtí teoretici bělosti.

7 Barad (1996, 2007) rozvíjela přístup ,,agentního realismu“, podle nějž je realita ,agentni““ v neustálém procesu stávání se, kdy jsou jevy nutně vzájemně propleteny. Hranice mezi předmětem a významem a objekty a subjekty vědění nejsou předem dány, ale vznikají v rámci vzájemně propleteného vztahování se nebo „intra-akcí“. Je důležité, které řezy se realizují, a vyvolává to odpovědnost, protože různé řezy vedou k různým materiálním stávání se. Více k úvodu do agentního realismu v kontextu neoliberální univerzity viz také Zábrodská a kol. (v tisku). 
Snaha o excelenci se stejně jako jinde projevila především v podobě maximalizace produktivity a výstupů, zejména publikací (nebo patentů) prošlých mezinárodním recenzním řízením, citačních indexů a mezinárodní spolupráce (Lorenz-Meyer 2012; Stöckelová 2012; Brink a Benschop 2012).

Při prezentaci bylo naším cílem narušit hranice excelence tím, že otevřeme diskusi o tématech, které takto úzce vymezená snaha zastírá a někdy bagatelizuje. Kdyby byla vzata vážně, ústav by se $\mathrm{s}$ jejich přispěním mohl vyprofilovat jako místo, kde se dělá dobrá věda. Šlo o to, dát hodnotu různým projevům úspěchu (jako důraz na výuku, službu a kolegialitu), spolupráci vědců s dalšími společenskými aktéry, péči a společenskosti, které jsou nutné pro společensko-materiální reprodukci laboratoře jako legitimního prostoru pro provozování vědy a jako místa změny pro jednotlivé vědkyně a vědce, a nejistým kariérním vyhlídkám juniorských badatelek a badatelů a samostatných vědeckých pracovnic a pracovníků, mezi nimiž bylo mnoho žen. Jinými slovy, naším cílem bylo zasáhnout (interfere) (Haraway 1997; Law 2004; Barad 2007) do praxe excelence mezi badatelkami a badateli v instituci, která byla považována za celostátně úspěšnou a díky př́jmům $\mathrm{z}$ aplikace poznatků byla dobře finančně zajištěná - a domnívaly jsme se, že má potenciální svobodu realizovat excelenci a genderové vztahy odlišně. ${ }^{8}$

Pozvánku na naši prezentaci rozeslal jeden z účastníků našeho výzkumu přes interní adresár a jako upoutávku napsal: „Je to zajímavý experiment, kdy jsme se ze subjektu vědeckého zkoumání stali jeho objektem. Přijd’te se podívat, na co socioložky přišly! Zdá se, že jejich výsledky budou velmi kritické. Očekávám zajímavou, až bouřlivou diskusi. Nenechte si to ujít!“ (Vedoucí výzkumného týmu, muž, email 12. 7. 2010). Předpoklad, že naše zjištění budou „kritická“ a povedou $\mathrm{k}$,„̌̌ivé“ diskusi, mohl vyplynout $\mathrm{z}$ vědomí, že v průběhu práce v terénu jsme vyslechly různé stížnosti a kritiku ohledně náboru, propouštění a bibliometrického hodnocení, a také díky naší institucionální př́islušnosti a souvisejícímu angažmá v kontaktním centru Ženy a věda na Sociologickém ústavu a na Katedře genderových studí́. Označení sebe sama jako „objektu“ výzkumu, které zaznělo i na semináŕi, zjevně nevyjadřovalo ani tak obavu nebo nepohodlí v souvislosti s „objektifikaci““, jako spiše možnost objektů „mít námitky ${ }^{9} \mathrm{k}$ tomu, co se o sobě dozvědi“ (Latour 2000: 115). I když se někteř́ z klíčových účastnic a účastníků našeho výzkumu, s nimiž jsme zůstaly ve sporadickém kontaktu, na poslední chvíli omluvili, seminár měl nakonec dobrou účast - 35-40 účastnic a účastníků od zástupkyně ředitele ústavu, vedoucích laboratoří a samostatných vědeckých pracovnic a pracovníků až po postdoktorské stážistky a stážisty a doktorandky a doktorandy. Zúčastnila se také naše spolubadatelka z českého týmu KNOWING Tereza Stöckelová (Sociologický ústav AV ČR).

8 Slovy Haraway ,potřebujeme odlišně nastavit materiálně-semiotické aparáty - ohnout paprsky technických věd tak, aby se na filmy našich životů a těl nahrály slibnější interferenční vzorce“ (Haraway 1997: 16). Teoretizování je pro Haraway (a Law a Barad) hmotnou praxí, která pomáhá ustavit a posílit určité agentní reality. 


\section{Mobilizace praxe zajištující rovnost na Západě}

Svou část prezentace jsem nazvala „Za ženy ve vědě“. Název sebevědomě vyjadřoval můj záměr posunout hranice komplexu ,gender a věda“ za úzký rámec hledání problémů začlenění a kariérního postupu u žen-vědkyň směrem k uvažování o tom, jak by se věda mohla změnit, aby vytvářela a obsáhla rozmanitější genderování. Abych uznala a následně zproblematizovala přesvědčení mnoha účastníků výzkumu, že vzorce nerovné účasti žen a mužů jsou nevyhnutelně utvářeny odpovědností žen za péči o děti, začala jsem terénním setkáním, kdy se mě starší vědec opakovaně ptal: „A co je na tom zajímavého? Podívejte se na něj (otočí se na svého mladšího kolegu). Má dvě děti a jeho manželka je s nimi doma - co se tady dá rozebírat? Jinak by nemohl ty děti mít“ (terénní poznámky 27. 11. 2007). Ve snaze rozklíčovat naturalizaci genderové odlišnosti jsem poukázala na to, že považovat ,ženy ve vědě“ za neexistující téma odpovídá neexistenci plánů genderové rovnosti a poradců monitorujících nábor, udržení a rozvoj kariéry žen a mužů, se kterými jsme se setkali v partnerských zemích projektu KNOWING - v Rakousku, Finsku a Velké Británii. Neexistují ani veřejné subjekty, které by udělovaly ceny za excelenci v praxi genderové rovnosti. Takové ceny, argumentovala jsem dále, se udílejí například v rámci britského programu Athena SWAN. Bývají vyvěšeny na stránkách kateder na význačných místech vedle žebříčků hodnocení výzkumu a propagují a odlišují tak pracoviště, kde se dělá dobrá věda. Chtěla jsem tím říci, že známkou excelence by mohlo být spíše odhodlání prosazovat genderovou rovnost než to, že je považována za neexistující téma.

Představovat si odlišnou podobu věcí pomocí poukazu na praxi odjinud, neboli - řečeno více zpříma - snažit se strategicky mobilizovat ochotu promítnout vizi vlastního úspěchu do praxe západních institucí, které jsou vnímány jako úspěšnější, samozřejmě nikdy není nevinné. Felt a Stöckelová (2009) ukázaly, jak imperativy „dohánění“ ve skutečnosti navrací české instituce do dichotomie Západu a zbytku světa, jejíž hranice se reprodukují právě pomocí tohoto druhu tabulkového hodnocení. A co je klíčové, obvykle zůstává nezpochybněno to, jaké napětí, jakou cenu a jaké potenciální omyly s sebou konkrétní mechanismy vytváření excelence nesou (Linková 2009; Lorenz-Meyer 2012). Zkoumání technologií rovnosti ukázalo, že tyto politiky často představují formalistická cvičení a mohou dokonce zakrývat to, co mají odhalovat: např́klad dá-li se dokumentace sexistických a rasistických postupů při sestavování akčních plánů použít jako měřítko dobré výkonnosti (Ahmed 2010). Inzerovat prosazování genderové rovnosti jako známku kvality a možnou konkurenční výhodu se blíží podnikatelskému způsobu obhajování rovnosti, kdy se najímání žen a profesionálů z menšinových etnických skupin odůvodňuje posilováním ekonomické výkonnosti, což zpětně znamená, že není-li rovnost zisková, neměla by se prosazovat. Navíc tendence podnikatelské rétoriky kvantifikovat, oddělovat od těla a deindividualizovat je v rozporu s participativnější obhajobou rovnosti pomocí sociální spravedlnosti a často opomíjí struktury zvýhodnění (Garforth a Kerr 2009).

Metodologicky můj odkaz na praxi excelence na Západě spadal spíše do modu kritiky než intervence. Law (2004) rozlišuje různé „,mody významnosti“, jimiž analytici „tvarují materiál tak, aby byl předmětem zájmu“ (Law 2004: 2), kritika ustavuje rozlišení faktu a hodnot, „přičemž fakta jsou více méně jasná, pokazily se však hodnoty“ (Law 2004: 3), a ty potřebují napravit. (Zde: účast žen není rovnoprávná, a to by se jako nutná součást vědecké excelence 
mělo napravit.) Oproti tomu modus interference poukazuje na různé ontologie (projevy praxe rovnosti) a popisuje, jak navzájem kolidují, posilují se či neutralizují. Interference chce pracovat s „hrubostí a podivností projevující se na konkrétních místech (Law 2004: 5), spíše než s hladkostí a vyvážeností; nekomentuje, ale narušuje“ (Hirschauer a Mol 1995: 380).

Záměrně jsem nechala otevrené to, co by praxe genderové rovnosti mohla obnášet, nyní jsem však přesvědčena, že jsem se této nevyhraněnosti měla věnovat podrobněji: že odpovědnost za to, jak si ženy a muži vedou ve vědě, je důležitá, ale nepostačuje k posouzení posunů směrem k (větší) excelenci, a zároveň že konkrétní podoba lokálních opatření zajištujících odpovědnost je - a ve skutečnosti musí být - otevřená diskusi a veřejnému dialogu (Shore a Wright 1999; Stöckelová 2012).

Představa, že by měřítkem excelence mohlo být odhodlání prosazovat genderové rovnosti, nebyla na semináŕi přijata. Při diskusích u oběda se ukázalo, že to mohlo být způsobeno jistotou vedoucích laboratoří, že již bez ohledu na gender a další parametry nerovnosti najali ty nejlepší a nejnadanější. Nebylo to tím, že by se opírali o spolehlivé mechanismy hodnocení, ale protože „člověk pozná talent, když ho vidi““ (vedoucí výzkumného týmu, muž, terénní poznámky 17. 7. 2010). K otázce, jak pracovat s napětími mezi zdánlivou samozřejmostí excelence a jejím nedostatečně jasným referenčním rámcem, se vracím později.

\section{Využití genderové statistiky}

Mezi doktorandy v ústavu bylo zhruba $40 \%$ žen, ale ženy vedly jen dvě z více než dvaceti výzkumných skupin. Jako nástroj k prozkoumání genderovaných vzorců účasti a jejich uvedení do kontextu jsem použila tzv. nůžkový diagram účasti žen a mužů ve vědě v Evropské unii (Evropská komise 2009: 73). Diagram na základě evropských statistik vzdělání (Eurostat) znázorňuje distribuci žen a mužů na různých akademických postech ve všech oborech od pregraduálních studentů po nejvyšší pozice (obvykle profesorské). Dva samostatné grafy ukazují, že v roce 2006 (podobně jako v roce 2002) bylo mezi pregraduálními studenty více žen (55\%) než mužů (45 \%), na úrovni doktorandů se poměr mužů zvýšil (52 \% mužů ku 48 \% žen) a na nejvyšší akademické úrovni zastoupení mužů dosáhlo $82 \%$ a žen bylo 18 \% (89 \% mužů ku $11 \%$ žen v přírodovědných a technických oborech).

Poukázala jsem na to, že takto vysoce agregovaná data mažou rozdíly mezi disciplínami a zeměmi, a proto pouze naznačují nadměrné zastoupení mužů-vědců na vysokých akademických postech. ${ }^{10} \mathrm{~S}$ pomocí diagramu jsem představila genderová studia jako úhel pohledu kladoucí otázku, jak k takovému rozložení dojde. Na semináři jsem řekla, že

v genderových studiích se nezastavujeme u myšlenky, že existují biologické ženy a biologičtí muži a tyto vzorce vzniknou prostě proto, že ženy nejsou dost ambiciózní. Naše data jasně ukazují, že na počátku kariéry mají muži a ženy stejné aspirace ohledně vědecké kariéry. [...] Gender jako

10 Po rozložení dat Eurostatu podle zemí je procento žen na nejvyšších postech i nadále nejvyšší v zemích a sektorech, kde jsou nejnižší mzdy a další zdroje (Blagojević a kol. 2004). Při posledním sčítání v roce 2010 šlo o terciární vzdělání v Rumunskou, Lotyšsku a Chorvatsku (Evropská komise 2012). Tento vzorec poukazuje na redukcionismus modelů, kde je genderové excelence dosahováno prostě přijímáním a udržováním více žen na pracovišti. 
společensko-vědní koncept neznamená ženy - slouží k tomu, aby zpochybnil myšlenku, že pohlavní rozdíly jsou přirozené, že jde o vrozené identity, které se projevují právě v tomto druhu statistik. Je zde zájem zkoumat moc a nerovnost, to, jak dojde k propojení vůdcovství nebo představivosti vědce s maskulinitou, jak se sexuální rozdíly institucionalizují... (Dagmar, přepis semináře)

Mobilizujeme-li „pplitickou moc statistické reprezentace“ (Lawson 1995), abychom legitimizovali genderové rozdíly jako fakt (matter of fact) - a genderová studia jako legitimní tradici zkoumání - a pak hrajeme na potenciál statistiky „provokovat otázky“ (tamtéž) o tom, jak tyto kategorie a vzorce vznikají, abychom je transformovali v předmět zájmu (matter of concern), narazíme na řadu problémů. Začněme s tím, co je zjevné: statistiky jako Eurostat definují gender jako pohlaví (nebo pohlavní kategorii). Sčítají již diferencované a zformované akademické posty, které zastávají muži a ženy jako jednotlivci $\mathrm{v}$ jednom bodě v čase. Takovéto prosté znázornění nás nijak spontánně nevede $\mathrm{k}$ výše uvedené otázce, jak vznikají kategorie mužskosti a ženskosti a jak jsou v rámci konkrétních praxí spoluutvářeny tak, že mohou a nemusejí odpovídat pohlavně určeným tělům. Podobně, jsou-li jednotlivé poměry účasti žen a mužů položeny na progresivní osu akademických postů, grafy pak reprodukují tzv. „typickou akademickou kariéru“ (Evropská komise 2009) - lineární postup od pregraduálního studenta či studentky po profesora či profesorku. To jsme zpochybnili již dřive: vzhledem $\mathrm{k}$ nedostatku postů vedoucích skupin je tato kariéra dosažitelná jen pro velmi malé procento badatelů a badatelek. I když tento diagram zobrazuje nadměrné zastoupení mužů na vy̌̌ších akademických postech, jen těžko se na jeho základě zpochybňuje normalita i maskulinita této ideální představy o kariéře.

Navíc jsem ve svém dobře míněném úvodu do fungování perspektivy genderových studií nedocenila neurčitost a napětí obsažené $\mathrm{v}$ genderu jako analytické kategorii a objektu poznávání, který ani přesně neodpovídá pohlaví, ani není zcela vyvázán z pohlavně definovaného těla (např́íklad Moore 2004). Tím, že jsem zdůraznila rozdíl mezi pohlavím a genderem, jsem gender představila jako vymezený objekt, ale také znovu vytyčila hranici mezi př́rodou a kulturou - i když jsem prohlásila, ,že gender je samožrejmě ošemetný, nesourodý, máme celou škálu různých mužskostí a ženskostí, které vidíme [v různých praxích], protože gender neexistuje čistě o sobě, vždycky se protíná s věkem, kulturou..." (Dagmar, přepis semináře). Jinými slovy, tvrzení, že gender není o „biologických ženách a mužích“, př́lišs dobře nesedělo k názornosti nůžkového diagramu, který otázku „maskulinizace“ vědy redukoval na nerovné rozložení mužů a žen na akademických postech.

Tato napětí, o nichž jsem se nezmínila, mohla přispět spíše k potvrzení než ke zpochybnění normality a přirozenosti „nedostatečného zastoupení žen ve vědě“. A některé z reakcí, které jsem dostala po semináři, skutečně mezi genderem a pohlavím nerozlišovaly a uzavíraly tak prostor, který jsem se mezi nimi snažila vytvořit. Muž-vědec, který se ptal ,a co je na tom zajímavého?“, u oběda mobilizoval biologickou vědu, když poznamenal: „neukázala nám evoluce, že o štěňata se vždycky staraly samice?"“ (terénní poznámky 17. 7. 2010); a účastník-vedoucí laboratoře měl pocit, že jsme $\mathrm{k}$ interpretaci našich dat použily „předem promyšlené kategorie“" (tamtéž). Jeho postřeh, že dvě kolegyně odmítly jeho nabídku, aby se při transformaci instituce hlásily o místo vedoucí laboratoře, byl vnímán jako důkaz, že vedoucí laboratoře musejí být „alfa samci“ a ženám celkově chybí testosteron, který je k vedení laboratoře jako úspěšného podniku potřeba (tamtéž). 


\section{Skládání a sdílení zkušeností}

Abych vyzdvihla mnohost (nenormativních) praxí genderování, postavila jsem vedle sebe výpovědi různých aktérů. Například názor, že „hlavním problémem není diskriminace vědkyn̆ - problém tkví v nedostatku volných míst v jeslích a školkách“ (vedoucí výzkumného týmu, muž, email 15. 4. 2006) - podaný jako zkušenost z první ruky ,protože moje žena (také vědkyně); se nachází přesně v této situaci“ (tamtéž) -, a výpověd’ o tom, jak se genderové rozdíly zhmotnily v podobě osobní a institucionální nečinnosti ve vědě bez zjevného uvědomění či záměru.

Nemyslím, že by to bylo tak, že profesor rozhodne: „Nepodpořím vás, protože jste žena.“ Nemyslím, že by si to nějak uvědomovali, ale prostě ženy neberou v úvahu. Jako by je ani nenapadlo, že žena by také mohla být vedoucí. [...] Purkyněho stipendium pro nově nastupující vědce doposud nikdy nedostala žena. ${ }^{11}$ A já osobně nevěrím, že by neexistovala ani jediná žena, která by si takovou podporu nezasloužila. Důvodem je, že ústav musí někoho na stipendium navrhnout. To je podle mě vysvětlení. Protože je mnoho dobrých žen. Znám mnoho držitelů Purkyněho stipendia, kteří mají mnohem horší výsledky než já. Ale mě na Purkyněho nikdy nikdo nenavrhl [...]. Protože si říkají: „Musíme získat toho a toho vědce. Je hodně úspěšný a má rodinu, takže potřebuje dostatek peněz“ [...]. Ale nikdy nepomyslí na nějakou ženu, která třeba není ještě ani vdaná. Takže tohle jsou dva důvody, proč právě ona vlastně tolik peněz nepotřebuje [smích]. A i kdyby rodinu měla, tak by nebyla jako vědec užitečná [smích]. (vědkyně, výzkumný rozhovor, 12. 8. 2008)

Tato výpověd' hovoří o genderujících účincích ticha a absence podpory ve vědě vyvozených z genderovaných vzorců udílení grantů (i z osobních zkušeností - o jejím kariérním postupu se, na rozdíl od postupu jejích mužských kolegů, v laboratoři nikdy nemluvilo). Pozornost se zde přesunuje $\mathrm{z}$ poskytování péče o děti $\mathrm{k}$ homosociálním praxím ve vědeckých komunitách a věk, nižší postavení, rodinný stav a vnímaná pohlavní kategorie se protínají takovým způsobem, že vytvářejí genderové rozdíly v kariérním postupu. Ovšem na rozdíl od ostatních příběhů o praxích genderování, například mého (esencialistického!) tvrzení, že ženy v laboratoři často upozad'ují ,,svou“ ženskost - které bylo okamžitě napadnuto otázkami, ,jak jste to změřila?“ (postdok) nebo poukazem na nepraktičnost „strojení se“ do laboratoře (vědkyně) -, po této výpovědi nastalo ticho: nevyvolala další výpovědi, ani potvrzující ani odporující; nezdálo se, že by narušila výhradní zaměření na uspořádání péče o děti ve skutečnosti jako by nerezonovala se zážitky ostatních př́ítomných, ani na ně nezapůsobila.

Tento dojem zesílil, když mě po semináři oslovili juniorští badatelé a chtěli, abych vysvětlila, proč se ženy nestávají vedoucími laboratoří, a badatelka, která na úvod prostě vykřikla: „Nevěřím, že bych nemohla být vedoucí laboratoře, kdybych chtěla!“ (Terénní poznámky, 17. 7. 2010.) Podpořil ho i běžný výrok, že v akademickém světě ,člověk pozná talent, když ho vidí“.

Vzbudit rezonanci s výpověd'mi o praxích genderování a vyvolat úvahy o jiných možnostech bylo obtížné pravděpodobně jak kvůli obsahům, tak diskurzivním kontextům. Výše uvedená výpověd' byla $\mathrm{v}$ podstatě $\mathrm{v}$ rozporu $\mathrm{s}$ uctívaným ideálem univerzity jako pravé

V roce 2012 to stále platí. 
meritokracie, kde ti nejtalentovanější a nejpracovitější postupují kupředu a zaujmou nejmocnější místa. Scully (2002: 400) uvádí, že „pokud začneme pochybovat o tom, že univerzita je meritokracií, možná bude nutná redistribuce, a to je děsivá neznámá“ (tamtéž). Takové pocity mohou být obzvláště výrazné $\mathrm{v}$ českém kontextu, kde o mechanismy znovunastolení meritokracie bojují sami vědci (Linková a Stöckelová 2012). Z hlediska pozic, z nichž se promlouvalo, byla výpověd' vědkyně bez dlouhodobé smlouvy dále delegitimizována naší vtělenou př́tomností jako relativně mladých badatelek-žen. Poznámky jako „byla to škoda“ (vědkyně), že se výzkumu neúčastnili žádní mužští badatelé, jasně naznačovaly, že naše ženství bylo považováno za nedostatek, ne-li prímo za předpojatost. Stejně tak významná byla pozice našich protějšků - zpochybnění neustálého spojování žen-vědkyň s rodinnou péčí se totiž dotýkalo také osobního životního uspořádání mnoha mužů-vědců, kteří „by se museli ptát, co dělají jejich ženy doma“" (Claudia Born, osobní korespondence; 19. 7. 2010).

Jednou z metodologických obtíží při skládání kontrastních výpovědí aktérů je to, že přednášející tyto různé „hlasy“ nevyhnutelně aranžuje. Udělala jsem to dosti zřetelně, když jsem spojila dvě výpovědi s hodnotově nabitými pojmy „přepjaté viditelnosti péče o děti“ a „,neviditelné diskriminace“, čímž jsem př́liš jednoznačně předznamenala jejich způsoby čtení/poslechu. Při pohledu zpět se zdá důležité neomezovat se při skládání výpovědí na dvě (Keller 1987), ale předložit škálu různých výpovědí o praxi genderování, které si navzájem odporují. Mohla tam patřit úvaha vedoucí laboratoře-ženy o tom, jak bibliometrické hodnocení diskriminuje ty, kdo práci přerušili, nebo praxi velmi úspěšného vedoucího laboratoře-muže, který se aktivně podílel na péči o děti a plánoval odejít na otcovskou dovolenou takové praxe mohly postupně vyprovokovat otázky o nevyhnutelnosti nepřerušované lineární kariéry a dvanáctihodinového dne jako jediné možné kariérní dráze ve vědě.

Ve snaze vymezit genderování ve vědě jako performativně ustavené v každodenních praxích (např́íklad Butler 2004) a jako potenciální měřítko excelence mě mobilizace praxe rovnosti, genderové statistiky a výpovědi marginalizovaných aktérů vedly $\mathrm{k}$ tomu, že jsem znovu vytyčila hranice mezi př́rodou a kulturou, Východem a Západem a dominantními a podřizenými výpověd’mi. Byl-li přístup ,ženy ve vědě“, kdy je problém absence kariérního postupu žen spojován s jejich odpovědností za péči o děti a nedostatkem agresivity, postaven proti př́stupu „gender ve vědě“, který problematizuje neviditelnost maskulinních standardů a jejich účinků, bylo obtížné hovořit o nejistotách a nevyhraněnostech genderu a uznat, že jsem ve své vlastní narativní praxi čerpala z obou pozic. Namísto toho, abych obhajovala sjednocenější prrístup, jsem prohlásila, že pro mou prezentaci mohl být př́nosem podrobnější rozbor rozporů a interferencí $\mathrm{v}$ rámci obou těchto strategií a mezi nimi.

Nyní chci zkoumat, jak účastníci semináŕe artikulovali své zájmy - konkrétně, jak popisovali a vymezovali odpovědnost a hranice mezi vědou a společností a českými a západními praxemi $v$ reakci na naši prezentaci.

\section{Vytyčování hranic kolem odpovědnosti}

O odpovědnosti se diskutovalo obzvláště živě v souvislosti s našimi intervencemi v souvislosti se sexistickým vtipkováním a hodnocením výzkumu. Zatímco o procesu hodnocení výzkumu jako nástroje měření výkonnosti a excelence se hojně debatovalo v průběhu 
samotného výzkumu, sexuální humor a vtipkování se moc neprobíraly - i když výrazně kontrastovaly s proklamovanou genderovou neutralitou vědeckých laboratoří. Nyní postupně prozkoumám obě tyto diskuse.

\section{Odmítání odpovědnosti aneb svoboda dělat sexuální vtipy}

Když jsem hovořila o tom, jak se genderová odlišnost utváŕí v každodenních praxích, zmínila jsem se také o tématu sexistického vtipkování. Abych ochránila anonymitu zúčastněných, promluvila jsem souhrnně o tom, jak některé vědkyně, včetně zahraničních postdoktorálních stážistek, vnímaly takové slovní jednání jako ponižující a vylučující. Moje vysoce moralizující tvrzení, že „bychom si všichni měli uvědomit, jaké pocity mohou takové vtipy vyvolávat v těch, na koho jsou směřovány“, předpokládalo nutnost (sebe)regulace takového chování. Když jsme diskutovali o tom, jak vytvořit více přijímající pracovní prostředí, vrátil se jeden juniorský vědec k praxi sexistického vtipkování. Zamýšlel se, „,kolik českých postdoků se také necítí dobře, protože myslím, že to víc záleží na české kultuře, protože bych řekl, že muž z Iránu, který by sem přijel na postdok, by se také necítil pohodlně“ (muž-vědec, přepis), a přesunul tak téma do oblasti kulturních odlišností. Podle něj by se touto praxí mohli cítit dotčeni také (nezápadní) muži. Zároveň tak označil sexistické vtipy za neoddělitelnou součást „české kultury“ a cizinci, kteří se rozhodnou pracovat v českých laboratořích, se tedy této praxi musejí přizpůsobit. Když jsem namítla, že výhrady k sexistickým vtipům nemají jen zahraniční zaměstnanci, diskuse se stočila $\mathrm{k}$ otázce, zda by mohla či měla být regulována.

Marcela: Měli jsme také velmi pozitivní př́klady, kdy vedoucí laboratoří nastavili velmi př́isné standardy s nulovou tolerancí k sexistickým a rasistickým vtipům, je tedy zřejmé, že se dá jít do důsledků, že některé věci jsou nepřijatelné. [...] Samožrejmě mezi muži a ženami probíhá spousta škádlení, a to je zábavné, [...] takže, víte, nejde samozřejmě o to, eliminovat veškeré tyto interakce ale-

Moderátor (vedoucí výzkumného týmu, muž): Ale jde, vlastně ano. To je to nebezpečí v tom. $\mathrm{Na}$ jedné straně máte problém lidí, kteří se urážejí a cítí se nepohodlně, na druhé straně je tu nebezpečí sterilních politicky korektních situací, kdy se lidé bojí cokoliv říci. A já si myslím, že to druhé nebezpečí je ve skutečnosti větší. Dovolte mi zeptat se přítomných žen: cítí někdo tady opravdové pohoršení nad vtipy od mužů, takže to začne-

Vědkyně 1: Je spousta vtipů o mužích-

Moderátor: Je spousta vtipů o mužích, spousta vtipů o tom, že pocházím z [místo původu], spousta vtipů o Slovácích, hodně vtipů o Moravácích. To všechno zastavíme? [...] Všechny tyto věci mají nechtěné důsledky, na to se snažím poukázat.

Dagmar: To neberu, [jméno moderátora]! ... Aby se jednalo o nepřátelské pracovní prostředí, jak se tomu ř́íká ve Spojených státech-

Moderátor: Vím, co myslíte, to nenávidím [smích].

Dagmar: -musí jít o opakované vtipkování, ne jednorázovou poznámku, takže myslím, že tam hranice je-

Vědkyně 2: Já myslím, že je to prostě hranice vkusu, jak daleko můžete nechat někoho zajít a je 
prostě moje odpovědnost, ve skutečnosti asi prostě někomu řeknu, at' toho nechá. To je něco, co se nedá opravdu kontrolovat-

Tereza: Pro mě je prostě důležité jasně ř́íci, že vtipy nejsou jenom vtipy; vtipy jsou velmi silným společenským nástrojem uplatnění moci. A myslím, že cílem diskusí, jako je tato, by mělo být vytvořit prostor, v němž se lidé cítí natolik pohodlně, aby se bránili, když se takový vtip třeba objeví.

Vědkyně 2: Myslím, že tady by na to určitě byl prostor. Nemůžete vydávat žádné pokyny zvenku a říkat „tohle ř́kat můžete a tohle ne“. To je nebezpečné.

(přepis semináře)

Z debaty o sexistickém vtipkování se stal spor o hranice, kdy přednášející tvrdily, že existuje hranice mezi škádlením a obhroublým sexistickým či rasistickým vtipkováním, zatímco zúčastněné vědkyně a vědci existenci takové jasné hranice popírali. V průběhu sporu, připomínajícího podobné debaty ve Spojených státech (například Lawrence 1990), byla regulace sexistického vtipkování přirovnávána k vynucené ,politické korektnosti“, kdy je bráněno svobodě projevu. Americká legislativa o nepřátelském pracovním prostředí byla odsuzována jako pomýlená, podkopávající to, o co usilovala. V souvislosti s „nebezpečím“ regulace byl zmiňován také potenciálně subverzivní význam vtipů - ,vítězný prríklon k nekontrole oproti kontrole... neoficiálním hodnotám oproti oficiálním“ (Douglas 1968: 366) - který byl významnou strategií, jak ,rríkat pravdu“ za státního socialismu. Podstatné je, že odpovědnost za „vytyčení hranice“ nebyla připisována urážejícímu subjektu. Byla ponechána na těch, kdo se při takových setkáních cítí poškozeni - a tím, že odmítají postavení oběti, tuto odpovědnost také zdánlivě přijímají (podobně jako ve fyzikálních laboratořích ve Skandinávii, Hasse a Hojer 2008). ${ }^{12}$ Tento stav vychází z předpokladu stejných podmínek pro všechny, který jsem pravděpodobně podpořila, když jsem nepohovořila o tom, proč jsou sexistické významy tak „mocným společenským nástrojem prosazování moci“: že totiž mobilizují významy, které kolují ve společnosti obecněji a navracejí jednotlivce do podřízených pozic. Nepopsala jsem ani to, jaké škody může sexistické vtipkování působit v konkrétních situacích (kromě prosté urážky). Z výpovědí o tom, že byla „v šoku“ a „opravdu jsem nebyla schopna adekvátně zareagovat" (studentka), nebo o zoufalství z toho, že je kolektivně odsouzena jako suchar, tedy vyplývalo, že badatelky mohly doslova ztratit řeč a v některých situacích se zdálo, že jejich emocionální zranění mohlo jen těžko něco vynahradit. Není ani třeba dodávat, že $\mathrm{v}$ takových prrípadech se anuluje dobro otevřenosti a svobody projevu.

Stále se domnívám, že sexistické vtipkování je praxe, která volá po vytyčení hranic. Ovšem v rámci účinnější intervence jsem mohla podrobněji rozebrat různé reakce v ústavu, namísto toho, abych ,hovořila za“ marginalizované aktéry a nesla morální váhu utrpení ostatních“ (Hirschauer a Mol 1995: 380). Dále jsem mohla využít př́ležitost prozkoumat, proč badatelky a badatelé vnímají sexuální humor jako nepostradatelný pro každodenní práci, když vedoucí laboratoří tvrdili, že v jejich laboratořích nezáleží na tom, zda ,je někdo žena, žid nebo černoch“" (vedoucí výzkumného týmu, muž, přepis).

12 Studie Hasse a Hojer dále ukazuje, že i když byly podány stížnosti, správa a vedoucí laboratoří je zřídkakdy dále zpracovávali, zvláště byli-li pachatelé považováni za úspěšné vědce. 


\section{Přijímání odpovědnosti aneb nevyjasněnosti mechanismů vyłváření excelence}

Diskuse o odpovědnosti a citlivosti ${ }^{13}$ ve vědě byla prŕznivější v souvislosti s technologiemi hodnocení výzkumu, které pomáhají vytvářet excelenci z hlediska výstupů a výkonu. Moderátor tuto diskusi zahájil postřehem, že všudypřítomnost kvantitativního hodnocení je odezvou na skutečnost, že na českých univerzitách často „kvalitní lidé nejsou na mocenských pozicích“ (vedoucí výzkumného týmu, muž, přepis semináře). Jedná se o odkaz státně-socialistického režimu, kdy byly vedoucí pozice a přístup ke zdrojům podmíněny příslušností ke komunistické straně. Tvrdé hodnocení výzkumu má podporu při obnovování meritokracie. Tento étos byl v rozporu s naším zjištěním, že tyto režimy hodnocení vedly vědce $\mathrm{k}$ tomu, aby „měnili zpo̊sob, jakým publikují, a témata zkoumání ve prospěch oblastí, kde jsou peníze“ (Marcela, přepis semináře), což vedlo k následující výměně.

Moderátor: Je to skutečně tak, že hodnocení impakt faktoru a snaha publikovat mění vědecká témata? Děláme výzkum jinak, protože víme, že prřístí únor [není slyšet: bude] tenhle žebříček impakt faktoru na člověka na rok?

Juniorský vedoucí výzkumného týmu, muž: Mohlo by to ovlivnit dlouhodobé směřování. Když něco vypadá sexy, možná pár věcí zkusíte... Také sledujete, co je sexy a co přitahuje pozornost, ne?

Moderátor: To, co je sexy, je atraktivní, protože je to zajímavé, ale já se nezměním [není slyšet: styděl bych se], já dělám to, co považuju za zajímavé [...]. Takže je to opravdu tak?

Vědkyně: Částečně ano. Mě by třeba opravdu zajímaly simulace důležité pro atmosférické systémy, ale v biologických vědách je $o$ tolik více peněz, a to mě nutí dělat také simulace biologických systémů.

Moderátor: No, to je o financování, ne hodnocení-

Vědkyně: A také, protože je těžší získat financování, je také těžší v této oblasti publikovat, takže se musim dívat i na jiné oblasti.

Zástupkyně ředitele: ...lidé dělají, co mohou, v podmínkách, ve kterých jsou. Ale chci se připojit [k moderátorovi] a říct, že tlak na hodnocení je, ale stejně bych řekla, že většina $\mathrm{z}$ nás dělá vědu z vlastního zájmu.

(přepis semináře)

Je pozoruhodné, že na rozdíl od diskusí o genderu spolu účastnice a účastníci výzkumu navzájem nesouhlasili, zde při tvrzení moderátora, že existuje jasná hranice mezi prováděním výzkumu a jeho hodnocením. Konkrétně ti, kdo nezastávali vyšší posty vedoucích laboratoří, zpochybňovali autonomii vědy svými výpověd'mi o tom, jak jejich výzkum ovlivňuje to, co je považováno za konkurenceschopné, financovatelné a publikovatelné v časopisech s vysokým impakt faktorem (IF). Tak vyplynula na povrch napětí mezi akademickou svobodou a financováním a hodnocením jako mechanismy vytváření excelence, a také zapletení

13 Haraway (2008) hovoří o „response-ability“ (schopnosti citlivě reagovat). Tento pojem propojuje praktický a etický způsob práce s citlivostí a její kultivaci skrze vztahování se k jiným tělům. 
badatelů do mocenských vztahů, které se zhmotňují a projevují, mají-li badatelé pocit, že se jim zmenšuje manévrovací prostor.

Intervence Terezy Stöckelové, abychom se také podívali na to, ,jak [důraz na IF] mění celou infrastrukturu publikování ve vědě... [např́iklad] jak editoři významných časopisů pracují na udržení svého impakt faktoru a činí velmi zpochybnitelné volby ohledně toho, co publikují a co ne, aby si ho udrželi“ (přepis semináře), nastartovala další debatu. S odkazem na své členství v redakčních radách a roli hodnotitelů a recenzentů nabízeli výše postavení účastníci a účastnice celou škálu příkladů, jak se impakt faktory formují pomocí jiných praxí, než jakou je kvalita publikovaných článků. Tyto náhledy na omylnost recenzních řízení však zůstaly povětšinou nepropojené se zpochybňováním jejich úlohy při zajišt'ování excelence a představováním si jiných možností - což bylo nakonec označeno za téma pro další diskusi.

Moderátor: $\mathrm{OK}$, o impakt faktoru bychom mohli mluvit donekonečna. Velmi důležitým tématem by bylo, jak významné časopisy vlastně utvárejeji to, jak se věda dělá a co se dělá, tito lidé mají neuvěritelnou moc, která se vlastně nebere v potaz. Tito lidé rozhodují, co to je excelence, co to je věda, co je sexy a co stojí za to financovat. (přepis semináře)

V tuto chvíli se postřeh, že výzkum ovlivňují redakční a finanční rozhodnutí, jeví jako uznaná skutečnost. Volání po odpovědnosti však směřuje na redaktory časopisů s vysokým IF, kteří mají moc stanovovat, co se počítá jako dobrá věda, i když otázka, jak (a komu) by měli být odpovědni, zůstává nápadně otevřená. Je důležité, že tento krok vytváří hranici mezi „,normálními vědci“ a „mocnými editory“, a zakrývá tak mocensky významnou úlohu, kterou sehrávají seniorští vedoucí laboratoří jako editoři, recenzenti a mentoři v publikačních sítích, včetně kontaktů s nejvýznamnějšími editory (viz též Traweek 1988).

Co to znamená pro to, jak gender ve vědě učinit předmětem zájmu? Při pohledu zpět se mi zdá, že genderové badatelky a badatelé by měli pracovat s vyslovenými nevyjasněnostmi ohledně výzkumu a jeho hodnoty, zejména mezi ideálem meritokracie a omylností mechanismů hodnocení, například recenzních řízení. To by znamenalo začít diskutovat o vědecké excelenci nikoliv z pohledu nespokojenosti těch, kdo se cítí být vytlačováni na okraj, vyloučeni nebo poškozeni, ale těch, kdo ve vědě zaujímají ústřední místa, tedy vedoucích výzkumných skupin, a na základě př́íladů předpojatosti financování, publikování a recenzního řízení začít vytvářet představy o tom, jak by věda mohla být organizována jinak. Počínaje tím, že uznají-li vědci propletenost vědy a společnosti, mohlo by být snazší hovořit o praxích genderování, aniž by se předpojatosti a nerovnosti lokalizovaly nejprve a především do oblasti genderu, v protikladu k němuž se vědecké praktiky jeví jako neproblematické.

\section{Závěr}

Vzhledem k tomu, že se zdálo, že účastnice a účastníci odmítli zjištění výzkumu o genderu ve vědě, tvrdím v tomto článku, že strategie a praxe změny a narušování genderových hranic v akci se možná nevyrovnají feministické analýze způsobů jejich ustavování, udržování, zpochybňování a překračování. Tím, že se nepodařilo z genderu učinit předmět zájmu, se znovu oživuje otázka, jak mluvit o genderu, aniž by se př́liš zjednodušil, jak realizovat genderové rozdíly a zároveň hovořit o moci, standardech a začlenění/vyčlenění. Na základě přesvědčení 
vycházejícího z feministických studií o vědě, že vyprávíme složitější příběhy, které neusilují o kontrolu nad tím, čeho dosahují, a že přijímáme odpovědnost za hranice, které sami konstruujeme, jsem uvedla, že často opomíjená praxe veřejných prezentací výzkumu, zejména jsou-li nahrávány, nabízí příležitost $\mathrm{k}$ přezkoumání intervencí badatelů a badatelek i reakcí a zájmů účastnic a účastníků výzkumu a k prozkoumání interakční dynamiky.

Ohledně zkoumání obrysů hranic na semináři s praktikujícími přírodovědci jsem zjistila, že impuls „zasáhnout“ mě vedl k zaměření se na zdánlivě snáze změnitelné oblasti genderových nerovností. Konkrétněji mě má snaha legitimizovat genderové vztahy jako prostor pro intervenci a potenciální excelenci vedla $\mathrm{k}$ tomu, že jsem mobilizovala praxe rovnosti na Západě, genderové statistiky o kariérním postupu a výpovědi marginálních aktérů způsoby, které znovu vytyčily hranice mezi př́rodou a kulturou, Západem a zbytkem světa, dominancí a subordinací, aniž bych se výslovně zabývala nevyjasněnostmi a nejistotami těchto hranic a genderu jako objektu poznání.

To neznamená, že by se badatelky a badatelé měli vyvarovat využívání takovýchto dat. Měli by však riskovat a poukázat na napětí mezi tím, co se smí a co se přehlíží, když určité druhy důkazů předkládají, a nabízet důkazy, které nesměřují $\mathrm{k}$ jasným řešením, ale otevírají další otázky. Uvedla jsem, že monokauzální a naturalizované chápání genderových vztahů, jež přinesli někteří účastníci a účastnice, lze nejlépe zpochybnit prezentací rozmanitějších genderových praxí. Namísto toho, abychom začali například od běžného postoje, že gender ve vědě není téma, a pak předložili protikladná data, slibnější narativní postup by mohl začít popisem a mobilizací genderových rozdílů, a následně prozkoumat, zda a kde jsou konkrétní praxe v souladu, rozporu, či se neutralizují. Dále, nenormativní výpovědi o praxi genderování nevyvolaly u účastníků odezvu a genderové hranice se kryly s hranicemi mezi vědou a společností, vytvářením a organizací poznání, odpovědností vlastní a odpovědností ostatních. Z toho vyplývá, že oproti tezi, že feministický výzkum začíná od marginalizovaných životů, mohou prezentace genderového výzkumu začít od zájmů mocných aktérů, zde v souvislosti s praxí zavádění meritokracie a propletení vědy a společnosti.

Bereme-li zájmy účastníků našeho výzkumu vážně, neznamená to, že je činíme konečnými arbitry platnosti našich analýz. Znamená to však postavit do popředí výzkumu schopnost feministického výzkumu vytvářet rezonanci, emoce, ostych, pochybnosti a protiargumenty. Pokud účastníci našeho výzkumu nemají čas číst naše zprávy, jak nám řekli v naší studii, znamená to přehodnotit a uznat veřejné prezentace výzkumu, které, jak uvádí Gunaratnam (2007), badatelky a badatelé i poskytovatelé financí jen zř́́dka berou v potaz - emocionálně, koncepčně a finančně. Aby se při prezentaci výzkumu mohla rozvinout její schopnost generovat nová pochopení, otázky a možnosti, neměli by badatelky, badatelé a financující agentury vytvářet jasné hranice mezi vedením výzkumu a šířením jeho zjištění. Vyprávění korozivních př́běhů může být nejproduktivnější, pokud jsou součástí výzkumu prezentace vznikajících zjiššení a pokud vyzývá $\mathrm{k}$ veřejné diskusi a sporům jako integrální a odpovědné součásti výzkumu jako takového. Takovéto dlouhodobé rozhovory-výměny budou pravděpodobně vzkvétat, budou-li se rozvíjet $\mathrm{v}$ souvislosti se společnými projekty a novými formami spolupráce (Marcus 2010). U genderových studií, kde koncepční metafora genderu do různé míry vstoupila do veřejné sféry a i nadále je ovlivňována myšlenkami a předpoklady převládajícími mimo akademický svět (Moore 2004: 74), může být takový proces obzvláště důležitý. 
Zároveň se jeví jako velmi důležité uvědomit si, že nemůžeme nikdy zcela vědět, jaké účinky mohou naše prezentace mít na různé účastnice a účastníky, mimo jiné proto, že konkrétní pochopení jednotlivých intervencí závisí na umístění a pozici badatelek a badatelů, posluchaček a posluchačů (Alcoff 1991). Některé naše intervence byly sice v daném okamžiku považovány za „sociální inženýrstvi““ (vedoucí výzkumného týmu, muž, terénní poznámky), později jsem se však s překvapením dozvěděla, že nový výzkumný plán ústavu obsahuje závazek ,vytvořit inspirující, multikulturní, prrátelské a současně kompetitivní prostředí pro odborný růst vědeckých pracovníků z ČR i ze zahraničí, a kultivovat nejvyšší etické i profesionální standardy odborné práce. Být institucí spolupracující, otevřenou, široce komunikující s veřejností, sdělovacími prostředky i školami“. Do mezinárodní poradní rady instituce byla poprvé jmenována žena-profesorka. Podle neformálních rozhovorů dvě ženy do těchto funkcí navrhl vedoucí laboratoře, který vylučoval možnost genderové diskriminace a při diskusi na semináři byl zmiňován jako typický „,alfa samec“. Když mezi sebou vedoucí laboratoří hovořili o kandidátkách, neformálně o nich hovořili jako o „holkách“ - podobně jako profesoři a profesorky - členové a členky jmenovacích komisí v nizozemské studii Brink a Benschop (2012). Odhodlání sledovat a prijímat takto komplexní nejednoznačnost věcí je charakteristickým znakem vyprávění korozivních příběhů o genderu.

Přeložila Tereza Kodíčková

\section{Literatura}

AHMED, Sara. Secrets and Silence in Feminist Research. In RYAN-FLOOD, R., GILL, R. (eds.). Secrecy and Silence in the Research Process. Feminist Reflections, London: Routledge, 2010, s. xvi-xxi. ISBN 978-0415605175.

ALCOFF, Linda. The Problem of Speaking for Others. Cultural Critique, 1991, č. 20, s. 5-32. ISSN 0882-4371.

BARAD, Karen. Meeting the Universe Halfway: Realism and Social Constuctivism without Contradiction. In NELSON, L.H. and NELSON, J. (eds.). Feminism, Science and the Philosophy of Science. Dordrecht: Kluwer Academic Publishers, 1996, s. 161-194. ISBN 0-7923-4611-4.

BARAD, Karen. Meeting the Universe Halfway. Quantum Physics and the Entanglement of Matter and Meaning. Durham: Duke University Press, 2007, ISBN 978-0822339175.

BLAGOJEVIC, Marina et al. Waste of Talents: Turning Private Struggles into a Public Issue. Luxembourg: Office for Official Publications of the European Communities, 2004, ISBN 92-894-6750-9.

BRINK, Marieke van der; BENSCHOP, Yvonne. Gender Practices in the Construction of Academic Excellence: Sheep with Five Legs. Organization, 2012, roč. 19, č. 4, s. 507-524. ISSN 1350-5084.

BUTLER, Judith. Undoing Gender. London: Routledge, 2004, 273 s. ISBN 0-415-96923-9

DOUGLAS, Mary. The Social Control of Cognition: Some Factors in Joke Perception. Man, 1968, roč. 3, č. 3, s. 361-376. ISSN 0025-1496.

ENGLAND, Kim. Getting Personal: Reflexivity, Positionality and Feminist Research. The Professional Geographer, 1994, roč. 46, č. 1, s. 80-89. ISSN 0033-0124.

EUROPEAN COMMISSION. She Figures 2009: Statistics and Indicators on Gender Equality in Science. Brussels: Directorate General for Research. ISBN 978-9279113888. 
EUROPEAN COMMISSION. She Figures 2012. Statistics and Indicators on Gender Equality in Science. [online]. 2012 [cit, 2012-7-09]. Dostupná na <http://ec.europa.eu/research/ sciencesociety/document_library/pdf_06/she_figures_2012_en.pdf>

FAULKNER, Wendy. The Power and the Pleasure? A Research Agenda for "Making Gender Stick" to Engineers. Science, Technology \& Human Values 2000, roč. 25, č. 1, s. 87-119. ISSN 0162-2439.

FELT, Ulrike, STÖCKELOVÁ, Tereza. Modes of Ordering and Boundaries that Matter in Academic Knowledge Production. In FELT, U. (ed.). Knowing and Living in Academic Research: Convergence and Heterogeneity in Research Cultures in the European Context. Prague: Institute of Sociology, 2009, s. 41-124. ISBN 978-8073301569.

FRANKLIN, Sarah; LURY, Celia; STACEY, Jackie. Global Nature, Global Culture. London: SAGE, 2000. ISBN 978-0761965992.

FUSS, Diana. Essentially Speaking: Feminism, Nature \& Difference. New York: Routledge, 1989. ISBN 978-0415901338.

GARFORTH, Lisa; KERR, Anne. Women in Science: What's the Problem? Social Politics, 2009, roč. 16, č. 3, s. 379-403. ISSN 1072-4745.

GUNARATNAM, Yasmin. Where is the Love? Art, Aesthetics and Research. Journal of Social Work Practice, roč. 21, č. 3, s. 271-287. ISSN 0265-0533.

HARAWAY, Donna. A Cyborg Manifesto: Science, Technology and Socialist-Feminism in the Late Twentieth Century. Socialist Review, roč. 80, s. 65-108. ISSN 0141-2442.

HARAWAY, Donna.Modest_Witness@Second_Millenium. New York, London: Routledge, 1997. ISBN 978-0415912457.

HARAWAY, Donna. The Promise of Monsters: a Regenerative Politics for Inappropriate/d Others. In HARAWAY, D. (ed.). The Haraway Reader. New York: Routledge, 2004, s. 63-124. ISBN 978-0415966887.

HARAWAY, Donna. When Species Meet. Minneapolis: Minnesota University Press, 2008. ISBN 978-0816650460.

HASSE, Cathrine; HOJER, Maja. Acknowledging Materiality as Agential Literacy. In OLESKY, E. H., PETÖ, A, WAALDIJK, B. (eds.). Gender and Citizenship in a Multicultural Context. Frankfurt: Peter Lang, 2008, ISBN 978-363156966.

HEMMINGS, Clare. Why Stories Matter: The Political Grammar of Feminist Theory. Durham: Duke University Press, 2011. ISBN 978-0822349167.

HIRSCHAUER, Stefan; MOL, Annemarie. Shifting Sexes, Moving Stories: Feminist/Constructivist Dialogues. Science, Technology and Human Values, 1995, roč. 20, č. 3, s. 368-385. ISSN 0162-2439.

JACOBSON, Matthew F. Whiteness of a Different Colour. European Immigrants and the Alchemy of Race. Cambridge, MA: Harvard University Press, 1999. ISBN 978-0674951914.

KELLER, Evelyn Fox. On the Need to Count Past Two in our Thinking about Gender and Science. New Ideas of Psychology, 1987, roč. 3, č. 2, s. 275-287. ISSN 0732-118.

LATOUR, Bruno. When Things Strike Back: a Possible Contribution of "Science Studies" to the Social Sciences. British Journal of Sociology, 2000, roč. 51, č. 1, s. 107-123. ISSN 0007-1315.

LATOUR, Bruno. Why Has Critique Run Out of Steam? From Matters of Fact to Matters of Concern. Critical Inquiry, 2004, roč. 30, č. 2, s. 225-248. ISSN 0093-1896.

LAW, John. Enacting Naturecultures: A Note from STS [online]. 2004. [cit. 2009-08-13] Dostupné na $<$ http://www.lancs.ac.uk/fass/sociology/papers/law-enacting-naturecultures.pdf $>$

LAWRENCE, Charles R. If He Hollers Let Him Go. Regulating Racist Speech on Campus. Duke Law Journal, 1990, roč. 39, č. 3, s. 431-483. ISSN 0012-7086.

LAWSON, Victoria. The Politics of Difference: Examining the Quantitative/Qualitative Dualism in Post-Structuralist Feminist Research. Professional Geographer, 1995, roč. 47, č. 4, s. 449-457. ISSN 0033-0124. 
LINKOVÁ, Marcela. Ne každý úspěch se počítá: excelence a genderování vědecké dráhy v př́rodních vědách. In STÖCKELOVÁ, T. (ed.). Akademické poznávání, vykazování a podnikání: Etnografie ménici se české vědy. Praha: SLON, 2009, s. 72-99. ISBN 978-8074190032.

LINKOVÁ, Marcela; STÖCKELOVÁ, Tereza. Public Accountability and the Politicization of Science: The Peculiar Journey of Czech Research Assessment [online]. Science and Public Policy, 2012 [cit. 2012-08-07]. Dostupné na: <http://spp.oxfordjournals.org/content/early/2012/ 05/29/scipol.scs039.abstract?keytype=ref\&ijkey=3pNTD8ZoJs0cqIn>

LORENZ-MEYER, Dagmar. Nový pohled na problém ,žen ve vědě‘: Tři mody genderového jednání v akademickém výzkumu. In STÖCKELOVÁ, T. (ed.). Akademické poznávání, vykazování a podnikání: Etnografie měnicí se české vědy, Praha: SLON, 2009, s. 101-133. ISBN 978-8074190032.

LORENZ-MEYER, Dagmar. Visceral Gendering and a Politics of Connectivity. Women's Studies International Forum, 2011, roč. 34, č. 5, s. 562-569. ISSN 0277-5395.

LORENZ-MEYER, Dagmar. Locating Excellence and Enacting Locality. Science, Technology and Human Values 2012, roč. 37, č. 2, s. 241-263. ISSN 0162-2439.

MARCUS, George E. 2010. Collaborative Options and Pedagogical Experiment in Anthropological Research on Experts and Policy Processes [online]. 2010 [cit. 2012-08-07]. Dostupné na $<$ http://www. iiac.cnrs.fr/IMG/pdf/Collaboration_and_anthropological_research.pdf>

MASSEY, Doreen. Masculinity, Dualisms and High Technology. Transactions of the Institute of British Geographers. New Series, 1995, roč. 20, č. 4, s. 487-499. ISSN 0020-2754.

MINH-HA, Trinh. She, The Inappropriate/d Other. Discourse, 1986/7, č. 8, s. 3-43. ISSN 0730-1081.

MOL, Annemarie. The Body Multiple. Durham: Duke University Press, 2002. ISBN 978-0822329176.

MOL, Annemarie; LAW, John. Boundary Variations: An Introduction. Environment and Planning D: Society and Space, 2005, roč. 23, č. 5, s. 637-642. ISSN 0263-7758.

MOORE, Henrietta. Global Anxieties: Concept-Metaphors and Pre-Theoretical Commitments in Anthropology. Anthropological Theory, 2004, roč. 4, č. 1, s. 71-88. ISSN 1463-4996.

PERRONS, Diane; POSOCCO, Silvia. Globalising Failure. Geoforum, 2009, roč. 40, č. 2, s. 132-135. ISSN 0016-7185.

POTTER, Elizabeth. Gender and Boyle's Law of Gases. Bloomington: Indiana University Press, 2001. ISBN 978-0253214553.

PUIG De LA BELLACASA, Marie. Matters of Care in Technoscience: Assembling Neglected Things. Social Studies of Science, 2011, roč. 41, č. 1, s. 85-106. ISSN 0146-1435.

SCULLY, Maureen A. Confronting Errors in the Meritocracy. Organization, 2002, roč. 9, č. 2, s. 396-401. ISSN 1350-5084.

SHORE, Chris; WRIGHT, Susan. Audit Culture and Anthropology. The Journal of the Royal Anthropological Institute, 1999, roč. 5, č. 4, s. 557-575. ISSN 1359-0987.

STAR, Susan Leigh. Power, Technology and the Phenomenology of Conventions: On Being Allergic to Onions. In LAW, J. (ed.). A Sociology of Monsters. London: Routledge, 1991, s. 126-156. ISBN 978-0415071390.

STÖCKELOVÁ, Tereza. Immutable Mobiles Derailed: STS, Geopolitics and Research Assessment. Science, Technology and Human Values, 2012, roč. 37, č. 2, s. 286-311. ISSN 0162-2439.

TRAWEEK, Sharon. Beam Times and Life Times. The World of High Energy Physicists. Cambridge, MA: Harvard University Press, 1988. ISBN 978-0674063488.

WOLLSTONECRAFT, Mary. The Vindication of the Rights of Woman. London: Everyman's Library, 1992. ISBN 978-0460871730.

ZÁBRODSKÁ, Kateřina et al. Šikana jako intra-aktivní proces na neoliberálních univerzitách. Biograf: časopis pro kvalitativni výzkum, 2011, č. 56, s. 33-55. ISSN 1211-5770. 


\section{Autorka}

Dagmar Lorenz-Meyer vyučuje na Katedře genderových studií Fakulty humanitních studií Univerzity Karlovy v Praze a v současné době působí jako výzkumná pracovnice v Centru genderového výzkumu na Uppsalské univerzitě. Ph.D. v oboru genderových studií získala na britské London School of Economics a publikuje o mezigenerační politice, feministickém aktivismu a studích vědy. Je spoluzakladatelkou pracovní skupiny s názvem European Feminist Materialisms (Evropské feministické materialismy) v rámci evropské asociace genderových studií ATGENDER.

Kontakt: d.lorenzmeyer@gmail.com 